\title{
ASSESSMENT OF CORPORATE SOCIAL RESPONSIBILITY PERFORMANCE AND STATE PROMOTION POLICIES: A CASE STUDY OF THE BALTIC STATES
}

\author{
Jintao LU(D) ${ }^{1,2^{*}}$, Licheng REN ${ }^{1,2}$, Chong ZHANG $^{1}$, Mengshang LIANG ${ }^{1}$, \\ Josef ABRHÁM ${ }^{3}$, Justas STREIMIKIS (D) 4,5 \\ ${ }^{1}$ Department of Business Administration, School of Economics and Management, \\ Taiyuan University of Science and Technology, 030024 Taiyuan, China \\ ${ }^{2}$ Research Center for Corporate Social Responsibility, \\ Taiyuan University of Science and Technology, 030024 Taiyuan, China \\ ${ }^{3}$ Department of Trade and Finance, Faculty of Economics and Management, \\ Czech University of Life Sciences Prague, 16500 Praha-Suchdol, Prague, Czech Republic \\ ${ }^{4}$ Lithuanian Institute of Agrarian Economics, V. Kudirkos g. 18, \\ 01113 Vilnius, Lithuania \\ ${ }^{5}$ University of Economics and Human Science in Warsaw, Okopowa 59, \\ 01-043 Warsaw, Poland
}

Received 07 December 2019; accepted 07 March 2020

\begin{abstract}
The development of Corporate Social Responsibility (CSR) initiative is formed by several cultural, economic, social, political and institutional factors which have an impact on setting the priorities and advancement of CSR practices. The aim of this study is to assess CSR performance at the country level. In order to achieve this aim, the main drivers and barriers of CSR initiatives were identified and systematized based on literature review. The policies to address these barriers were analysed and discussed. The framework for the assessment of CSR performance was developed based on the analysis and assessment of the quality of political-regulatory, economic and social environment, implemented public policies to promote CSR and successes that were achieved by countries in implementing recommendations for public policy advancement. The indicators from Venture Capital and Private Equity Country Attractiveness Index, CSR policies areas reviews and EU recommendations for the improvement of public policies linked to the CSR were applied for assessing the CSR performance. The empirical analysis and the assessment of CSR performance in the Baltic States was performed based on the developed framework and policy recommendations that were developed for other countries, taking into account the priorities of "The Belt and Road" project that was initiated by the Chinese government and aiming at sustainable development and global risk mitigation.
\end{abstract}

Keywords: Corporate Social Responsibility, state policies, governance indicators, policy performance index, The Baltic States.

JEL Classification: Q01, Q35, Q51.

*Corresponding author. E-mail: lut2002@163.com

This is an Open Access article distributed under the terms of the Creative Commons Attribution License (http://creativecommons. org/licenses/by/4.0/), which permits unrestricted use, distribution, and reproduction in any medium, provided the original author and source are credited. 


\section{Introduction}

Nowadays, Corporate Social Responsibility (CSR) has become the primary approach to fulfil sustainable development on the micro level. CSR plays an important role in dealing with the main global challenges such as the instability, climate change and poverty. Based on this background, related international initiatives were proposed by countries, organizations etc., for example, "The Belt and Road" project, that was initiated by China (Chen et al., 2019) with 66 involved countries, aims to deal with global challenges by using common efforts of businesses and governments. The good aspects of the public policies to promote CSR in selected countries can be useful for all the countries along "the Belt and Road" in the investigation of their current situations, and the advanced experiences can propose several key policy implications for "The Belt and Road" project to reach an "all-win" result for all the involved countries.

Though the CSR is a voluntary choice of organizations, the governmental policies can have an important effect on promoting CSR initiatives (Lu et al., 2019a). There are various drivers and barriers of CSR initiatives. The state policies and measures aiming to promote CSR are among the drivers, while the main barriers are in relation to the lack of information (or information asymmetry), and other issues linked to cultural, economic and social development.

There are several studies dealing with the barriers and drivers of CSR (Lu et al., 2019a, 2019b). Though many authors tried to outline what are the main drivers and barriers of CSR practices, it still has remained uncertain (Crilly et al., 2016; Servaes \& Tamayo, 2013; Epstein et al., 2014). Fewer studies explored the CSR performance and the influencing factors on the implementation of CSR initiatives consistently (Desai, 2016; Coluccia et al., 2018).

The study by Campbell (2007) highlighted the institutional factors including cultural traits, laws, regulations and institutionalized norms, all of which have important impacts on CSR initiatives. The study by Jackson and Apostolakou (2010) analysed the influence of different institutional factors in different cultural environment on the public policies to promote CSR in the EU countries. Its findings indicate that, countries with strong institutions have achieved low CSR performance. The same results were confirmed by the study conducted by El Ghoul et al. (2017), which provided that CSR initiatives have a greater value in countries with weaker institutions. However, other studies found a strong positive correlation between strong institutions and CSR development (Dhaliwal et al., 2012; Lu et al., 2019c). Ioannou and Serafeim (2012) found that the cultural traits, political and education system are the most important drivers of CSR initiatives. George and Antonis (2016) as well proved that strong institutions have a positive influence on the CSR performance in a country. The study by García-Sánchez et al. (2016) assessed the CSR performance in 20 developed economies and proved that a strong institutional environment promotes CSR performance in a country. Another study by Coluccia et al. (2018) as well confirmed these findings. Therefore, all studies stressed that social, political and legal factors have an impact on the penetration of CSR, though with varying consequences.

There is a lack of studies linking state policies to promote CSR with barriers and drivers of CSR initiatives. The EU has established legal acts to promote CSR initiatives in the Member States (MS). 
However, there is quite a diverse situation among the EU MS in terms of implementing policies to promote CSR initiatives and achieved results in sustainable development as well the effectiveness of economic, social and environmental policies, which are targeting the same issues on the macro level as CSR initiatives are addressing on the micro level. Another important issue is the CSR performance in a country. There are no developed frameworks for the assessment of CSR performance on the macro level that would allow comparing and ranking countries and applying good practices that have been achieved in the other countries.

This main input of this study is addressing this gap and development of a framework for the assessment of CSR performance in a country based on the quality of the politicalregulatory, economic and social environment, implemented state policies to promote CSR and overcome the barriers of CSR development and successes achieved by the countries in CSR-related policy support area.

The empirical analysis and assessment of CSR performance in the Baltic States were performed based on the framework developed in this study. The policy implications of the study can be applied in other countries for defining the priorities of state policies to promote CSR and addressing important economic, social and environmental barriers of the CSR at the country level.

The structure of the study is as follows: in the first section, the literature review on the main drivers and barriers of CSR is provided; in the second section, the analysis of public policies to support CSR initiatives in the EU is performed; in the third section, the framework for the assessment of CSR performance is developed; in the forth section, the state policies to promote CSR in the Baltic States are assessed based on the framework developed in this study; the discussion of the results is given in section 5 , which is followed by the conclusions.

\section{Literature review: barriers and drivers of CSR}

Despite the acknowledged positive effect of the CSR within a company, many issues are dispiriting firms from the decision to implement the CSR initiatives. The non-integration of CSR doctrines with the strategic objectives of the firm has been defined as a fundamental barrier for implementing the CSR initiatives by several authors (Emezi, 2014; Yuen \& Lim, 2016). Another important barrier is the non-acceptance of the corporate culture and a lack of senior management obligation to implement CSR. A company that does not have an appropriate cultural identity and does not follow ideology by recognizing the CSR values for long-term benefits of the firm faces an important barrier for the development of CSR initiatives (Yuen \& Lim, 2016; Krajnakova et al., 2018; Szwajca, 2018).

The implementation of CSR initiatives implies additional organizational costs, and the lack of financial support is also an important barrier of CSR development. The lack of other necessary resources such as qualified personnel makes another serious obstacle (Shen et al., 2015; Sinha \& Chaudhari, 2018; Ganushchak-Efimenko et al., 2018). Therefore, the lack of adequate theoretical and practical knowledge on the CSR among managers and higher staff causes barriers of the CSR initiatives in the company (Laudal, 2011).

Another important obstacle that hampers the dissemination of CSR practices which was identified by several authors is the non-existence of a mandatory regulatory regime in a 
country. Usually, the voluntary profile of CSR in a country and a lack of public policies to support CSR initiatives do not encourage firms to adopt CSR practices (Steurer, 2010; Elbassiouny \& Elbassiouny, 2019).

There is a growing public acceptance and motivation for firms to engage in CSR practices, as it is widely believed among the top managers that CSR practices can deliver the improvement of firm's ethics, economic transparency and efficiency and are anticipated to raise the loyalty of employees, reduce risks and provide innovations (Gligor-Cimpoieru \& Munteanu, 2015).

Other authors have stressed that in varying and risky business environment, CSR can guarantee firm's sustainability through the improvement of customers trust, enhanced corporation image, and the creation of strong brands (Mbogoh \& Ogutu, 2017). Moreover, CSR is anticipated to support business legitimacy and improve the ability of a firm to address the regulatory requests (Kurucz et al., 2008).

The driving force of CSR is the anticipated improvement in safety, health, and environmental performance. The CSR initiatives that are oriented towards safety, occupational health and mitigation of environmental impacts will have a positive impact on the employer's image, public acceptance, and positive employees' attitude on safety, health, safety, and environmental protection, which can lead to appropriate behavioural changes (Sowden \& Sinha, 2005). Other benefits in this area are linked to enhancing connection with stakeholders, and increasing their confidence on company, and influencing individual and organizational performance of the company positively (West et al., 2015).

The three main barriers that hamper the implementation of CSR can be identified as below: economic, social and political-regulatory environment on the micro or macro level, though they may be overlapping each other. The barriers of CSR on the micro level can vary among firms, and can be controlled by implementing specific managerial practices, shaping organizational culture and employing transformational leadership. While barriers on the macro level are linked to the external forces such as economic, social and political or regulatory circumstance of a country.

Economic barriers are linked to the lack of financial resources, high qualified human capital, and appropriate knowledge and expertise (Yuen \& Lim, 2016), those are barriers on either macro or micro level. In the underdeveloped countries, many companies face economic barrier as the implementation of CSR initiatives requires a lot of financial and human resources (Faisal, 2010). Therefore, poor economic situation of a country is an important barrier of the CSR development. In many firms, especially small and medium-sized enterprises (SMEs), there is not a special department dedicated to the implementation and management of the CSR initiatives. The shortage of qualified cadres is a very important barrier for the implementation of CSR initiatives on micro and macro levels (Alemagi et al., 2006; Dixon et al., 2008). As both the enactment and persistence of CSR practices require additional cost, to implement CSR initiatives may erode a companies' cost-competitiveness (Barnett \& Salomon, 2012). Hong, Kubik and Scheinkman (2012) revealed in their study that CSR expenditures amount billions of dollars for companies in the US, and they might outweigh all tangible benefits linked to the CSR practices.

Social barriers are another important group of CSR barriers (Jakusonoka \& Zarina, 2018). Low public acceptance of CSR initiatives does not create demand for the CSR in a country, 
and firms will not be adequately compensated for their CSR efforts by the society (Forbes, 2011). Consumers, especially in economically weak countries, are not willing to pay a premium for the CSR initiatives. However, customers usually choose to punish those with corporate hypocrisies or without CSR initiatives (Pruzan-Jorgensen \& Farrag, 2010). The report by the Boston Consultant Group (2011) provided that the lack of direct association between service quality and profits makes an important barrier for the CSR penetration in some industries. The low willingness to pay for CSR is found in business-to-business (B2B) industry (Haddock \& Fraser, 2008). Companies in B2B industry are far from their final customers in the value chain and are less oriented towards the implementation of CSR initiatives because of the lower involvement of stakeholders and the less pressure from them. In addition, CSR is a fuzzy terminology and contains different meanings for managers and societies in general. CSR is linked to sustainable development, business ethics, corporate governance and concept of citizenship and sometimes is overlapping each other. Therefore, the different views on CSR can have different impact on the manager's decision to implement CSR initiatives (Pawlik et al., 2012).

Political-regulatory and institutional barriers are linked with the political, legal, institutional and regulatory environment of a country which may be favourable or unfavourable for the penetration of CSR initiatives. The studies found that high scores of regulatory quality and accountability of rules and laws are very helpful for the penetration of CSR initiatives; However, it is found that political stability and governance effectiveness have minor effect on the CSR reporting and disclosure (Steurer et al., 2012; Coluccia et al., 2018).

Regulatory barriers such as the lack of universally agreed measurement systems and standards to assess the benefits of CSR practices are as well very important due to the limited social and environmental framework, which can be universally accepted by the companies (Jenkins \& Yakovleva, 2006; Jenkins, 2006; Coady et al., 2013). The indicators that are used in the CSR reports are not standardized, which makes the comparability difficult (Brammall, 2012). Especially in the highly-regulated industries, the standards and regulations for the environment and safety are very important. These constantly updated requirements are forcing companies in these industries to introduce CSR initiatives (Acciaro, 2014).

The availability of well-shaped policies dealing with economic, social and regulatory barriers, within or across sectors, can be considered as important drivers for the CSR development. These drivers can be categorized into three main groups: economic, social and political-regulatory drivers.

Economic drivers: economic situation of a country, economic structure, corporation image or reputation of a company, supporting mechanisms and policies implemented by government agencies, improved risk management, and competitive advantage.

Social and human drivers: public acceptance of CSR and the pressure from the local communities, customers, investors; non-governmental civil society, organizations and society in general.

Political-regulatory and institutional drivers: strong institutions and corporate governance, pressures from environmental and government organizations based on the legal acts, regulatory requirements, license to operate.

Therefore, the development of CSR initiatives is influenced by a variety of economic, social, political-regulatory and institutional factors which is discussed in more details as below. 
The economic development level and the structure of the economy have an impact on CSR approaches. The majority of state-owned companies have a positive impact on the penetration of CSR, as state-owned organizations are usually following different social and environmental standards compared to the private companies. The dominance of SMEs in industries does not always have a positive impact on the penetration of CSR practices, as they have less financial and human resources and are always facing bigger competitions from the markets.

Social and human factors, such as high public acceptance of CSR will have a positive impact on the development and implementation of CSR initiatives. Countries that are distinguished with low awareness of CSR have fewer policies focusing on raising awareness and building stakeholder engagement. Countries influenced by the economic crisis will put more emphasis on social policies, such as creating more employment opportunities for the young and vulnerable groups for social coherence.

Political-regulatory and institutional drivers of the CSR refer to national and regional governance structures. Policies will be implemented at this level in a more centralized administration, and more policies will be implemented at the local level in decentralized countries, which usually play a crucial role in CSR performance, because they are more effective by providing more opportunities for sharing experiences. Corporate governance and stakeholder engagement are well institutionalized in countries with a long-standing history of the CSR policies. In those countries where corporate governance has a long history, this permanent nature ensures a wide range of ongoing dialogues on the CSR issues among the relevant stakeholders. However, in countries without a long-standing history of CSR development, the stakeholder involvement is of an ad hoc nature and can not provide good conditions for the penetration of CSR practices in the country.

There have been a few attempts to characterize the CSR policies by themes and instruments without proper grouping or analysis in a consistent way (Steurer, 2010; Steurer et al., 2012; Pimentel et al., 2016; Albareda et al., 2007). The assessment of barriers and drivers of CSR and policies to overcome the barriers of CSR need to be done by studying the country cases. This would allow a deeper investigation of the country's situation, its political-regulatory, economic and social environment and the assessment of the already implemented public policies to promote CSR and their progress.

\section{EU policies to promote CSR}

There is a wide range of government-sponsored policies and measures driving CSR development in the EU. There are soft measures like raising awareness and hard measures like CSR implementation imposed by legal acts.

The setting of National Contact Point (NCP) is imposed by the the Organization for Economic Cooperation and Development (OECD) guidelines adhered by some governments of the EU MS. The aim of NCP is to assume promoting activities, handle various enquires and settle disputes relevant to the OECD guidelines.

National Action Plans (NAPs) on CSR were encouraged by the European Commission (EC) in defining the main actions to endorse CSR for the goals of the Europe 2020 strategy, 
and these NAPs can be regarded as very important tools of state policies in promoting CSR in the EU MS.

NAPs on business and human rights were encouraged by numerous international and EU organizations, including the UN Human Rights Council, the European Union, the Council of Europe etc. NAPs present the priorities and actions of states to implement the UN Guiding Principles on Business and Human Rights.

The setting of CSR priorities in alignment with global CSR practices is a popular approach among the EU MS. Many EU MS encourage reporting by applying the Global Reporting Initiative (GRI), UN Guiding Principles of Business and Human Rights, OECD Guidelines for Multinational Enterprises, and UN Global Compact principles.

Human rights and responsible supply chain management is imposed by the legal regulations in some EU MS. This area is addressed mostly in NAPs by the EU MS, taking into account the current situation of human rights violations and refugee problems in Europe.

CSR and SMEs are other important CSR supporting measures taking into account the importance of SMEs in the economies of EU MS. Therefore, the priority measures which support SMEs to develop CSR approaches are formulated in many EU MS agenda.

Social and employment policies targeting social inclusion in the EU 2020 strategy agenda are of particular importance for the EU MS which are intensely affected by the economic crisis. The following policies and measures are developed and implemented: knowledge exchange and dissemination of good practices, training, self-assessment, various support programmes for SMEs. The codes of conduct and standards are useful policy tools that prescribe ethical rules for business conduct linked to the environmental and social issues of CSR.

The raising of consumer awareness and promotion of responsible business are among the top priorities of public policies, as CSR performance in a country depends on how important economic, social and environmental CSR issues are perceived by firms and their stakeholders (customers, investors, consumers and the society). The raising awareness of the CSR among businesses and their stakeholders is the main interest of government in CSR promotion. Among the most common ways of raising public awareness are: the stakeholder dialogues and discussion fora, CSR campaigns and trainings, CSR conferences etc. Labels are informational devices that can assure customers that the production process, the product or the company satisfies the specific social and environmental standards beyond legal requirements and can lead customers take into account the CSR in their purchase decisions.

Reporting is a key for CSR initiatives, and many MS have already required larger companies to report on their CSR performance, as the European Commission has developed special regulations in this area at the EU level. Companies that have experienced strong pressure from stakeholders are among the first to publish CSR reports.

Education and training alongside with raising the awareness among customers and the society cause growing recognition of CSR generally. The MS have developed the curricula for business managers, and the educational and training systems to raise CSR awareness among post-graduates.

Sustainable public procurement (SPP) is an important public policy driving CSR initiatives, as public sector is an important player in the European market. The government acting in a socially responsible way provides a good example and can create financial incentives for socially responsible firms through favouring them in public procurement procedures. 
Socially responsible investments (SRIs) have become very important in the context of recent financial crisis. The SRIs have become major issues for publicly traded companies, as it integrates ethical, social and environmental aspects into the investment decisions. The SRIs favour companies with high CSR performance and exclude companies of certain industries like alcohol, tobacco and gambling.

Financial reporting obligations and anti-corruption policies have an important impact on the development of CSR initiatives, although state policies focus limitedly in this area in the EU. The low quality of institutional indicators, including corruption perception, is an important challenge for businesses in many new EU MS, where many negative behaviour patterns were inherited from their socialist past.

Climate change and environmental sustainability issues are addressed by many policies and measures implemented by the EU MS. Taking into account recent global challenges linked to the climate, climate change is a very important issue in the CSR agenda.

The EU MS have implemented different state policies to promote CSR with identified 14 areas which include: Availability of NAPs on CSR, Availability of NAPs on Business and Human Rights, Availability of National Contact Points, Alignment of CSR Policies with Global CSR Approaches, Human Rights and Responsible Business, CSR and SME, Social and Employment Policies, Consumer Awareness and Responsible Business Promotion, CSR Reporting and Disclosure, CSR in Education and Training, Sustainable Public Procurement, Socially-Responsible Investments, Financial Obligations and Anti-Corruption, CSR Approaches to Tackling Climate Change. Some MS have policies to promote CSR in all areas; some MS have implemented supporting state policies just in few CSR areas.

The differences among the EU MS are related to their economic, social, political-regulatory environment described in section 1 . The state policies and measures aiming to promote CSR are affected by the national meaning of CSR and the extent of CSR being seen as a voluntary action beyond legal norms and requirements.

In order to assess CSR performance of a country, many issues have to be taken into account, including the assessment of CSR drivers and barriers linked to the economic, social and political-regulatory environment.

\section{Framework for the CSR performance assessment}

The literature review on the drivers and the barriers of CSR and the analysis of state policies aiming to promote CSR in the EU have revealed that, in order to assess the CSR performance in a country, the political-regulatory, economic and social (PES) environment of a country need to be assessed. There are many frameworks, indexes and scores for the assessment of PES environment created by international institutions for various purposes: The Global Competitiveness Index and Rankings created by the World Economic Forum (World Economic Forum, 2019), Sustainable Governance Indicators created by Bertelsmann Stiftung (2019), Venture Capital and Private Equity Country Attractiveness (VCPECA) Index created by IESE Business School and EMLYON Business School etc, which is the most comprehensive index showing the attractiveness of a country based on the PES environment and can be applied for scoring and comparing countries in terms of their roles as the drivers or the barriers of the CSR initiatives. 
The VCPECA index covers 5 main areas regarding the drivers and the barriers of CSR: Economic Performance, Governance, Policy, Human and Social Environmental and Entrepreneurial Culture Quality (Groh et al., 2018).

The main EU public policies addressing CSR areas reviewed in Section 2 reveal the support from government agencies dealing with CSR barriers and drives of CSR initiatives in countries. As stated earlier, all these 14 areas are covered by the public policies in place which provide an important stimulus for the development of the CSR initiatives in countries.

The progress achieved by the countries in policy support linked to the CSR areas needs to be assessed as well. These criteria allow a static approach in the assessment of CSR performance of a country. Therefore, the three main criteria can be selected for the assessing and ranking of countries in terms of CSR performance on the country level, as such indicators like the number of CSR initiatives that are implemented by organizations in a country do not represent the real situation of CSR performance in that country.

Since there is no particular model for the assessment of CSR performance in a country, which can be applied for comparing and ranking countries, the following framework is proposed in Figure 1.

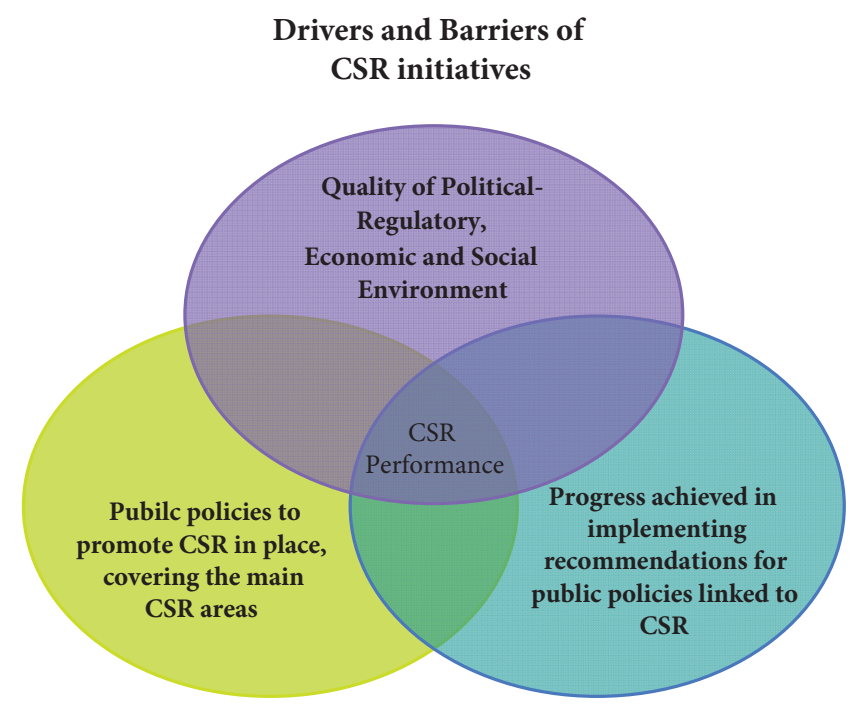

Figure 1. Conceptual framework of the study(source: created by the authors)

The developed framework presents three main criteria for assessment of CSR performance on the country level: 1) Quality of political, regulatory and social environment; 2) Available public policies to support CSR; 3) Achieved progress by countries in implementing recommendations for public policies enhancement in CSR related areas. These three main criteria for assessment represent also the main drivers or barriers of CSR development in the country.

The key criteria for the assessment of CSR performance in the selected EU countries based on the framework presented in Figure 1 are given in Table 1. The main criteria are the drivers of CSR or favourable PES environment for the development of CSR initiatives, the available public policies to promote CSR initiatives, and the progress achieved in implementing country's specific policy recommendations linked to the CSR areas by the EC. 
Table 1. The main criteria for the assessment of CSR performance (source: created by the authors)

\begin{tabular}{|l|l|}
\hline \multicolumn{1}{|c|}{ Criteria } & \multicolumn{1}{c|}{ Scores } \\
\hline The drivers of CSR or PES analysis & Scores: from 1 to 5 \\
\hline CSR promotion policies in place & Scores: from 1 to 5 \\
\hline Achieved progress in policies for addressing CSR issues & Scores: from 1 to 5 \\
\hline
\end{tabular}

The scores for the specific criteria given in Table 1 are assessed in details as below.

The quality of PES environment as the main drivers of CSR initiatives is assessed on a five-point scale:

5 indicates a superior quality of PES environment, meaning that a country is ranked in the range of 1-24, according to VCPECA Index (Groh et al., 2018), based on the Economic Performance, Governance, Policy, Human and Social Environmental and Entrepreneurial Culture Quality;

4 indicates a very good quality of PES environment, meaning that a country is ranked in the range of 25-49 according to the VCPECA Index, based on the Economic Performance, Governance, Policy, Human and Social Environmental, and Entrepreneurial Culture Quality;

3 indicates a moderate quality of PES environment meaning that a country is ranked in the range of 50-74 according to the VCPECA Index, based on the Economic Performance, Governance, Policy, Human and Social Environmental, and Entrepreneurial Culture Quality;

2 indicates a low quality of PES environment, meaning that a country is ranked in the range of 75-99 according to the VCPECA Index, based on the Economic Performance, Governance, Policy, Human and Social Environmental, and Entrepreneurial Culture Quality;

1 indicates an extremely low quality of PES environment, meaning that a country is ranked in the range of 100-125 according to the VCPECA Index, based on the Economic Performance, Governance, Policy, Human and Social Environmental, and Entrepreneurial Culture Quality.

The public policies in place to support the CSR initiatives in the identified 14 main areas of CSR in the EU MS are assessed on a five-point scale as below:

5 represents a situation when a Member State has public policies supporting in 12-14 areas of CSR;

4 represents a situation when a MS has public policies supporting in 9-11 areas of CSR;

3 represents a situation when a MS has public policies supporting in 6-8 areas of CSR;

2 represents a situation when a MS has public policies supporting in 3-5 areas of CSR;

1 represents a situation when a MS has public policies supporting in 0-2 areas of CSR.

The progress in implementing the 2017 country-specific policy recommendations by the European Commission for the EU MS linked to the CSR is assessed on a five-point scale as below:

5 represents that a Member State has implemented all measures that are necessary to address the CSR appropriately;

4 represents that substantial progress has been achieved by a country;

3 represents that some progress has been achieved by a country; 
2 represents that limited progress has been achieved by a country;

1 represents no progress achieved by a country.

In the following section, the framework for the assessment of CSR performance in the Baltic States is applied, and the empirical study is performed in the three Baltic States: Estonia, Latvia and Lithuania.

\section{Empirical study of the assessment of CSR performance in the three Baltic States}

The empirical study in the Baltic States is developed in the following steps: assessment of the quality of PES environment in the Baltic States based on the ranking of VCPECA Index, analysis of public policies to support CSR initiatives in the main CSR areas in the Baltic States, and the assessment of progress achieved by the countries in implementing countryspecific policy recommendations by the EC linked to the CSR. The final ranking of countries in terms of CSR performance is conducted by summing up the scores of each criterion.

\subsection{Assessment of PES environment in the Baltic States}

The economic growth opportunity is the main factor of a country which will determine its investment attraction. The infrastructure and pro-investment environment are very important as well. The economic activity, capital markets, tax systems, investor protection and corporate governance, human and social environment, business cultures and business opportunities in different countries are compared according to the VCPECA Index (Groh et al., 2018). 125 countries were ranked in 2018, among which Latvia was ranked the 49th, Lithuania the 45th, and Estonia the $44^{\text {th }}$. The 5 main areas of PES environment that are favourable for the development of CSR initiatives were selected in VCPECA Index: Economic Performance, Corporate Governance, Policy, Human and Social Environmental and Entrepreneurial Culture.

"Economic Performance" index was assessed based on "Economic activity" criterion from VCPECA Index and is comprised of 3 indexes: the size of the economy assessed by GDP in USD, the forecasted real GDP growth, \%, and the unemployment rate, \%.

The "Corporate Governance" index was assessed based on "Investor protection and corporate governance" criterion from VCPECA Index, which consists of 3 indexes: the quality of corporate governance, including 5 sub-indexes (disclosure, liability of director, shareholder involvement, legal rights and corporate boards effectiveness), the property rights security, including 3 sub-indexes (enforcement of contracts by laws, enforcement of property rights and enforcement of intellectual property rights) and the quality of legal environment, including 5 sub-indexes (judicial independence, impartial courts, legal system integrity, rule of law, the quality of regulations).

The "Policy" index that was assessed based on "Taxation" criterion from VCPECA Index: "Entrepreneurial tax incentives and administrative burdens", which is composed of 3 sub-indexes: entrepreneurship incentives or tax relief for main taxes, number of payments for taxes, time spent on paying taxes.

The "Human and Social Environment" index based on VCPECA Index consists of 3 indexes: education and human capital, which consists of 2 sub-indexes (the quality of education 
system, the quality of scientific research organizations), labour market rigidities, which consists of 4 sub-indexes (difficulty of hiring, rigidity of hours, difficulty of firing, firing costs), and bribing \& corruption, consisting of 3 sub-indexes (bribing and corruption perception, control of corruption, bribes).

The "Entrepreneurial Culture" index based on VCPECA Index consists of 5 indexes: innovation, consisting of 2 sub-indexes (the level of innovativeness and innovation capacity), the number of papers in scholarly journals, easiness in starting and keeping a business, which consists of 3 sub-indexes (procedures necessary to start a business, time necessary to start a business, the costs of starting a business), the easiness of closing a business, consisting of 3 sub-indexes (time needed to close a business entity, business entity closure costs, recovery rate) and company $R \& D$, including 2 sub-indexes ( $R \& D$ costs for firms, number of patents registered by companies).

The ranking of the Economic Performance, Corporate Governance, Policy, Human and Social Environmental and Entrepreneurial Culture of the Baltic States according to the VCPECA Index in 2018 is provided in Table 2.

Table 2. The ranking of the Economic Performance, Corporate Governance, Policy, Human and Social Environmental and Entrepreneurial Culture of the Baltic States according to the VCPECA Index in 2018 (Groh et al., 2018)

\begin{tabular}{|l|c|c|c|c|c|}
\hline Countries & $\begin{array}{c}\text { Economic } \\
\text { Performance }\end{array}$ & $\begin{array}{c}\text { Corporate } \\
\text { Governance }\end{array}$ & $\begin{array}{c}\text { Policy } \\
\text { Performance }\end{array}$ & $\begin{array}{c}\text { Human } \\
\text { and Social } \\
\text { Environment }\end{array}$ & $\begin{array}{c}\text { Entrepre- } \\
\text { neurial Culture }\end{array}$ \\
\hline Estonia & 82 & 21 & 8 & 33 & 41 \\
\hline Latvia & 43 & 41 & 17 & 46 & 49 \\
\hline Lithuania & 74 & 33 & 11 & 28 & 40 \\
\hline
\end{tabular}

As it can be seen from the data presented in Table 2, Estonia was ranked the highest according to the PES criteria except for the "Economic Performance". Lithuania is in the middle, and Latvia was ranked the lowest.

\subsection{Public policies to support CSR in the Baltic States}

The EC has published a comprehensive compendium on CSR policies in 2014 (EC, 2014). The public policies that were implemented in 14 main areas of CSR were reviewed: Availability of National Contact Points, Availability of NAPs on CSR, Availability of NAPs on business and human rights, Alignment of CSR policies with global CSR approaches, Human rights and responsible business, CSR and SME, Social and employment policies, Customer awareness and promotion of responsible business, CSR reporting and disclosure, CSR in education and training, Sustainable public procurement, Socially-responsible investments, Financial obligations and anti-corruption, CSR approaches to tackling climate change.

The Baltic States have National Contact Points that are established under the OECD guidelines. All Baltic States have adopted NAPs on CSR, and implemented NAPs under United Nations Guiding Principles on Business and Human Rights in 2015. There are only 9 out of 14 measures in NAPs with identified government agencies for the implementation. 
There is no ministry identified in NAPs for the Baltic States that would be responsible for follow-up of commitments, developed in the NAPs. The lack of specific framework to monitor and report progress achieved by NAPs is an important problem.

Lithuania has adopted NAPs on CSR in 2011 and clearly acknowledged that CSR is an essential pre-requisite for the sustainable development in the country. The strategic goal of the government is to secure essential conditions for the penetration of CSR initiatives and encourage enterprises to implement CSR practices.

Based on the analysis of Lithuanian NAPs and EC compendium on national public policies to promote CSR (EC, 2014), the state policies and measures are found/applied in the following CSR areas: Alignment with global CSR approaches, Human rights and responsible business, Consumer awareness and promotion of responsible business, CSR reporting and disclosure, CSR in education and training, Financial obligations and anticorruption.

The creation of the Responsible Business Forum in Estonia (RBF) in 2004 was the most important event of the CSR development in Estonia, and its CSR development is based on the strong partnership with the RBF. The support from the European Cohesion Fund was applied for the establishment of the national CSR platform in Estonia in 2010. Estonia established its NAPs on CSR in 2012. The main aims of the Estonian NAPs are as follows: to enhance competitiveness, to improve civil governance, to complement public social and environmental policies by ensuring benefits of business entities. The following actions are foreseen in the NAPs: a compendium of best CSR practices, the e-learning module on CSR for business entities, the establishment of a CSR award scheme, and many awareness-raising actions.

Based on the analysis of Estonian NAPs and EC compendium on national public policies to promote CSR (EC, 2014), the state policies and measures are applied in the following CSR areas: Alignment with global CSR approaches, Human rights and responsible business, Consumer awareness and promotion of responsible business, CSR reporting and disclosure, CSR in education and training, Sustainable public procurement, Financial obligations and anticorruption.

Latvia has declared in its NAP that, adopted in 2015, the sustainable development can be accomplished by implementing CSR principles in Latvia. It is anticipated that companies will operate in a socially responsible way, if the government can create a favourable environment for the development of CSR initiatives. The government policies can provide that even without legal enforcement, CSR initiatives can provide many benefits for business development and competitive advantages. The following main actions are foreseen in Latvia's NAPs: awareness raising campaigns and provision of information and training, provision of financial information and addressing corruption issues, promotion of CSR reporting, sustainable public procurement and promotion of CSR in SMEs.

Based on the analysis of Latvian NAPs and EC compendium on national public policies to promote CSR (EC, 2014), the state policies and measures are applied in the following CSR areas: Alignment with global CSR approaches, Human rights and responsible business, Consumer awareness and promotion of responsible business, CSR reporting and disclosure.

A positive transformation in the CSR practices could be noticed in the Baltic States based on the analysis of NAPs on CSR. The public policies to support CSR in the main CSR areas are reviewed in the Baltic States in Table 3. 
Table 3. Public policies to promote CSR in place in the Baltic States (source: created by the authors)

\begin{tabular}{|l|c|c|c|c|c|c|c|}
\hline $\begin{array}{c}\text { Coun- } \\
\text { tries }\end{array}$ & $\begin{array}{c}\text { Availability } \\
\text { of NAPs on } \\
\text { CSR }\end{array}$ & $\begin{array}{c}\text { Availability } \\
\text { of NAPs on } \\
\text { Business } \\
\text { and Human } \\
\text { Rights }\end{array}$ & $\begin{array}{c}\text { Avail- } \\
\text { ability of } \\
\text { National } \\
\text { Contact } \\
\text { Points }\end{array}$ & $\begin{array}{c}\text { Alignment } \\
\text { with } \\
\text { Global CSR } \\
\text { Approaches }\end{array}$ & $\begin{array}{c}\text { Human } \\
\text { Rights and } \\
\text { Responsible } \\
\text { Business }\end{array}$ & $\begin{array}{c}\text { CSR and } \\
\text { SME }\end{array}$ & $\begin{array}{c}\text { Social } \\
\text { and } \\
\text { Employ- } \\
\text { ment } \\
\text { Policies }\end{array}$ \\
\hline $\begin{array}{l}\text { Estonia } \\
(10)\end{array}$ & Yes & Yes & Yes & Yes & Yes & No & No \\
\hline $\begin{array}{l}\text { Latvia } \\
(9)\end{array}$ & Yes & Yes & Yes & Yes & Yes & No & No \\
\hline $\begin{array}{l}\text { Lithu- } \\
\text { ania } \\
(9)\end{array}$ & Yes & Yes & Yes & Yes & Yes & No & No \\
\hline $\begin{array}{l}\text { Awareness } \\
\text { and } \\
\text { Promotion of } \\
\text { Responsible } \\
\text { Business }\end{array}$ & $\begin{array}{l}\text { CSR Repor- } \\
\text { ting and } \\
\text { Disclosure }\end{array}$ & $\begin{array}{l}\text { CSR in } \\
\text { Edu- } \\
\text { cation } \\
\text { and } \\
\text { Training }\end{array}$ & $\begin{array}{l}\text { Sustainable } \\
\text { Public } \\
\text { Procurement }\end{array}$ & $\begin{array}{l}\text { Socially- } \\
\text { Responsible } \\
\text { Investments }\end{array}$ & $\begin{array}{l}\text { Financial } \\
\text { Obliga- } \\
\text { tions and } \\
\text { Anti-Cor- } \\
\text { ruption }\end{array}$ & $\begin{array}{l}\text { CSR } \\
\text { Approa- } \\
\text { ches to } \\
\text { Tackle } \\
\text { Climate } \\
\text { Change }\end{array}$ \\
\hline Estonia & Yes & Yes & Yes & Yes & No & Yes & No \\
\hline Latvia & Yes & Yes & Yes & No & No & Yes & No \\
\hline $\begin{array}{l}\text { Lithu- } \\
\text { ania }\end{array}$ & Yes & Yes & Yes & No & No & Yes & No \\
\hline
\end{tabular}

As one can notice from the information given in Table 3, the Baltic States have implemented similar state policies to promote CSR. Estonia has implemented public policies to support CSR in 10 areas, Lithuania and Latvia have public policies in 9 CSR areas. Estonia distinguishes with policies in place, which is targeting the sustainable public procurement.

\subsection{Progress on CSR policy support based on the country-specific recommendations provided by European Commission}

The European Commission (EC) performs its annual assessment of the economic and social situation in the EU MS in the light of the European Commission's Annual Growth Survey. In the 2018 survey, the EC encourages MS to implement reforms to foster productivity, resiliency and inclusiveness of the EU economy. MS should focus on the following issues in their economic policies: providing high-quality investments, implementing reforms to ensure the growth of productivity, inclusiveness, institutional quality, macroeconomic stability, including thorough public finance.

Based on the country reports, EC publishes Communication on 2019 European Semester: Assessment of progress on structural reforms, prevention and correction of macroeconomic imbalances, and results of in-depth reviews under Regulation (EU) No 1176/2011.

In recent years, the European Union has moved from economic recovery to solid expansion, and in 2019, Europe's economy is set to continue expanding, notwithstanding the more uncertain outlook that is projected. In order to ensure such a continuous economic expansion, the Member States will need to implement effective structural reforms, engage 
in responsible fiscal policies and lay out target investment strategies. A more effective link between the European Semester and the EU funding for 2021-2027, as presented in this year's package, will provide a necessary structure to ensure the effective delivery of the most target investment priorities.

For Estonia, in 2018 Semester, the country-specific recommendations have been made in the following areas:

- To expand the social safety net, especially for older people and vulnerable groups;

- To implement policies to reduce the gender pay gap by improving transparency of salaries in the business sector;

- To promote R\&D activities by creating an effective incentive for innovations.

For Latvia, in 2018 Semester, the country-specific recommendations have been made in the following areas:

- To improve public governance;

- To improve quality, accessibility and efficiency of the health system;

- To improve education and training system and make vocational education more applicable to the labour market demands.

For Lithuania, in 2018 Semester, the country-specific recommendations have been made in the following areas:

- To improve the design of tax and benefit system and promote voluntary tax paying culture and the use of smart tax administration system;

- To introduce the pension indexation from year 2018 in order to increase the fiscal sustainability of the pension system;

- To increase the efficiency of the general education system as well as adult learning;

- To improve health policies, ensure further consolidation of hospitals and strengthen disease prevention at the local level;

- To improve the effectiveness of public investment;

- To improve the research and innovation policy.

In Table 4, the assessment progress of implementing public policies linked to the CSR, based on the country-specific recommendations provided by the European Commission, are summarized for the Baltic States (European Commission, 2019a, 2019b, 2019c).

As one can notice from Table 4, the Baltic States have received quite similar countryspecific recommendations from the EU to improve public policies linked to the CSR area in 2019 European Semester for the assessment of progress in structural reforms, prevention and correction of macroeconomic imbalances, and results of in-depth reviews under Regulation (EU) No 1176/2011. In Country Report 2019, Estonia was assessed as a country that has achieved some progress in addressing 2018 country-specific recommendations. Lithuania and Latvia have received assessment in their Country Reports 2019 as having achieved limited progress in implementing the country-specific recommendations for 2018.

\subsection{Ranking of the countries based on the scores of CSR performance}

In Table 5, the scores of the three criteria regarding the assessment of CSR performance in the Baltic States are presented based on the framework developed in Figure 1 and the categories given in Section 3: the quality of PES environment, the availability of public policies to support CSR, the progress achieved in CSR-related public policies. 


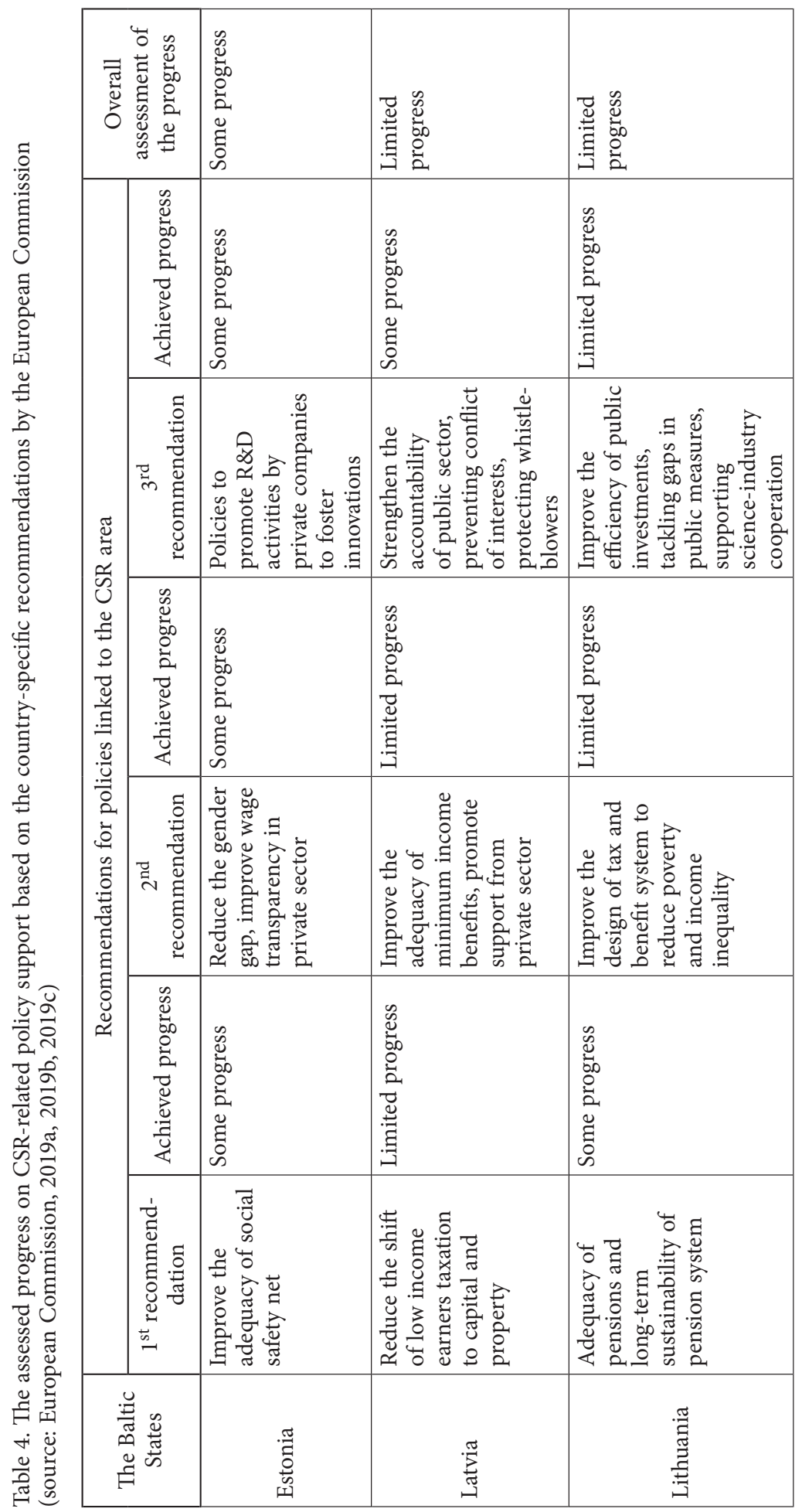


The PES environment, assessed on VCPECA Index, covers the main areas that are relevant to the CSR development: economic, governance quality, policy, human and social environment and entrepreneurial culture. The high scoring, according to VCPECA Index, in a specific area (Table 3) allows to allocate higher scores for the selected countries according to five-score scale.

The availability of public policies to support CSR was assessed based on the review, performed in Table 4, according to the main CSR areas. The countries were assessed according to these criteria by applying the five-point scale as well, as provided in the methodology of the study in Section 3.

The progress achieved in CSR-related public policies presented in Table 3, is evaluated according to five-point scale that is described in Section 3 as well.

Table 5. The assessment of CSR performance in the Baltic States (source: created by the authors)

\begin{tabular}{|l|c|c|c|}
\hline \multirow{2}{*}{\multicolumn{1}{c|}{ Criteria for assessment }} & \multicolumn{3}{|c|}{ The Baltic States } \\
\cline { 2 - 4 } & Estonia & Latvia & Lithuania \\
\hline Economic performance & 2 & 4 & 3 \\
\hline Governance quality & 5 & 4 & 4 \\
\hline Policy performance & 4 & 4 & 3 \\
\hline Human and social environment & 4 & 4 & 4 \\
\hline Entrepreneurial culture & 4 & 4 & 18 \\
\hline Total PES analysis & 19 & 20 & 9 \\
\hline CSR policies in place & 10 & 9 & 2 \\
\hline $\begin{array}{l}\text { Achieved progress in policies for } \\
\text { addressing CSR issues }\end{array}$ & 3 & 2 & 29 \\
\hline Total score & 32 & 31 & \\
\hline
\end{tabular}

As one can see from Table 5, Estonia is ranked the highest in terms of the CSR policies in place and progress achieved in implementing recommendations for the CSR policies, leading to the highest total score of CSR performance. Latvia has received the highest score in the ranking of countries, according to the quality of PES environment, leading to the second position in total ranking according to the CSR performance. Lithuania distinguishes among the Baltic States with the lowest ranking according to all three main criteria: PES environment favourable to CSR initiatives, CSR policies in place and the achieved progress in policies for addressing CSR issues, providing for the lowest ranking in total CSR performance assessment.

\section{Conclusions}

The analysis on the drivers and barriers of CSR indicated that companies lack state incentives to implement CSR, as there are some important political-regulatory, economic and social barriers hampering the penetration of the CSR. The state policies and measures are necessary 
to deal with these barriers. The social barriers can be effectively reduced by ensuring information about the benefits of the CSR for the sustainable development of a country provided.

The framework for the assessment of CSR performance in a country is developed in order to compare and rank countries in terms of their achievements in the penetration of CSR initiatives and creation of a favourable environment. The framework includes the assessment of political-regulatory, economic and social environment, policies to promote CSR in place and advancement of public policies linked to the CSR based on the country-specific recommendations by the EC.

The case study for the assessment of CSR performance, based on developed framework, was conducted in the three Baltic States. The ranking of the Baltic States, according to the CSR performance has identified the main barriers for CSR and public policies to promote CSR.

Estonia is ranked the highest in terms of the CSR policies in place and progress achieved in implementing recommendations for the CSR policies, leading to the highest total score of CSR performance. Latvia is ranked the highest in term of the quality of PES environment, leading to the second total score of the CSR performance. Lithuania distinguishes among the Baltic States with the lowest ranking in all three main criteria: PES environment favourable to CSR initiatives, CSR policies in place and the progress achieved in policies for CSR issues, leading to the lowest total score of CSR performance assessment.

There are important gaps in CSR performance, especially in the area of public policies to promote CSR in all Baltic States therefore these gaps can be narrowed by developing appropriate public policies to promote CSR initiatives.

The policies to promote CSR initiatives need to be implemented in all identified main areas of the CSR initiatives in the EU. The Baltic States are advancing in the right direction; however, it is necessary to stress that public policies still need to be developed in some important areas of the CSR in order to remove important political, economic and social barriers of the CSR penetration.

The study has limitations linked to scores applied for assessment of CSR performance. The approach of scoring applied in this paper is subjective therefore more advanced techniques as Multi-Criteria Decision Aiding tools and experts surveys can be applied for CSR performance assessment inn future research on this topic.

\section{Author contributions}

Conceptualization, J.L., L.R., and J.S.; methodology, J.L., and J.A.; validation, C.Z.; formal analysis, J.S. and M.L.; investigation, M.L. and L.R.; data curation, C.Z.; supervision, L.R.; writing - original draft preparation, J.L. and J.A.; writing - review and editing, J.L. and J.A.

\section{Acknowledgements}

The authors thank the anonymous reviewers and all the editors in the process of manuscript revision. 


\section{Conflict of interest}

The authors declare no conflict of interest.

\section{Funding}

This work was supported by the Program for the Innovative Talents of Higher Education Institutions of Shanxi (PTIT) under Grant (20191043); the Planning Program for Philosophy and Social Sciences of Shanxi under Grant (No. W20191020); Key R\&D Program of Shanxi Province, China (Social Development) under Grant (2019); Taiyuan University of Science \& Technology Scientific Research Initial Funding (TYUST SRIF) under Grant (No. W20182014 and No. W20192003).

\section{References}

Acciaro, M. (2014). A real option application to investment in low-sulphur maritime transport. International Journal of Shipping and Transport Logistics, 6(2), 189-212.

https://doi.org/10.1504/IJSTL.2014.059570

Albareda, L., Lozano, J. M., \& Ysa, T. (2007). Public policies on corporate social responsibility: The role of governments in Europe. Journal of Business Ethics, 74(4), 391-407. https://doi.org/10.1007/s10551-007-9514-1

Alemagi, D., Oben, P. M., \& Ertel, J. (2006). Implementing environmental management systems in industries along the Atlantic coast of Cameroon: Drivers, benefits and barriers. Corporate Social Responsibility and Environmental Management, 13(4), 221-232. https://doi.org/10.1002/csr.106

Barnett, M. L., \& Salomon, R. M. (2012). Does it pay to be really good? Addressing the shape of the relationship between social and financial performance. Strategic Management Journal, 33(11), 1304-1320. https://doi.org/10.1002/smj.1980

Brammall, R. (2012). How green are shipping companies? Southampton Solent University.

Campbell, J. L. (2007). Why would corporations behave in socially responsible ways? An institutional theory of corporate social responsibility. Academy of Management Review, 32(3), 946-967. https://doi.org/10.5465/amr.2007.25275684

Chen, J., Huang, J., Zheng, L., \& Zhang, C. (2019). An empirical analysis of telecommunication infrastructure promoting the scale of international service trade: Based on the panel data of countries along the belt and road. Transformations in Business \& Economics, 18(2), 124-139.

Coady, L., Lister, J., Strandberg, C., \& Ota, Y. (2013). The role of corporate social responsibility (CSR) in the international shipping sector.

https://corostrandberg.com/wp-content/uploads/2013/11/ubc-csr-in-shipping-denmark.pdf

Coluccia, D., Fontana, S., \& Solimene, S. (2018). Does institutional context affect CSR disclosure? A study on Eurostoxx 50. Sustainability, 10(8), 1-20. https://doi.org/10.3390/su10082823

Crilly, D., Hansen, M., \& Zollo, M. (2016). The grammar of decoupling: Stakeholder heterogeneity and firm decoupling of sustainability practices. Academy of Management Journal, 59, 705-729. https://doi.org/10.5465/amj.2015.0171

Desai, V. M. (2016). Under the radar: Regulatory collaborations and their selective use to facilitate organizational compliance. Academy of Management Journal, 59(2), 636-657.

https://doi.org/10.5465/amj.2014.0943 
Dhaliwal, D. S., Radhakrishnan, S., Tsang, A., \& Yang, Y. G. (2012). Nonfinancial disclosure and analyst forecast accuracy: International evidence on corporate social responsibility disclosure. The Accounting Review, 87(3), 723-759. https://doi.org/10.2308/accr-10218

Dixon, T., Colantonio, A., Shiers, D., Reed, R., Wilkinson, S., \& Gallimore, P. (2008). A green profession? A global survey of RICS members and their engagement with the sustainability agenda. Journal of Property Investment and Finance, 26(6), 460-481. https://doi.org/10.1108/14635780810908352

El Ghoul, S., Guedhami, O., \& Kim, Y. (2017). Country-level institutions, firm value, and the role of corporate social responsibility initiatives. Journal International Business Studies, 48(3), 360-385. https://doi.org/10.1057/jibs.2016.4

Elbassiouny, D., \& Elbassiouny, N. (2019). Diversity, corporate governance and CSR reporting: A comparative analysis between top-listed firms in Egypt, Germany and the USA. Management of Environmental Quality: An International Journal, 30(1), 116-136. https://doi.org/10.1108/MEQ-12-2017-0150

Emezi, C. N. (2014). Corporate social responsibility: A strategic tool to achieve corporate objective. Responsibility and Sustainability, 2(3), 43-56.

Epstein, M. J., Buhovac, A. R., Elkington, J., \& Leonard, H. B. D. (2014). Making sustainability work: Best practices in managing and measuring corporate social, environment and economic impacts ( $2^{\text {nd }}$ ed.). Berrett-Koehler Publishers.

European Commission. (2014). Corporate social responsibility national public policies in the European union-compendium 2014. https://ec.europa.eu/digital-single-market/en/news/corporate-social-responsibility-national-public-policies-european-union-compendium-2014

European Commission. (2019a). 2019 European semester: Assessment of progress on structural reforms, prevention and correction of macroeconomic imbalances, and results of in-depth reviews under Regulation (EU) No 1176/2011, Estonia. https://op.europa.eu/en/publication-detail/-/publication/b97988b43b6b-11e9-8d04-01aa75ed71a1/language-en

European Commission. (2019b). 2019 European semester: Assessment of progress on structural reforms, prevention and correction of macroeconomic imbalances, and results of in-depth reviews under Regulation (EU) No 1176/2011, Latvia. https:/op.europa.eu/en/publication-detail/-/publication/d27baa0d3b6b-11e9-8d04-01aa75ed71a1/language-en

European Commission. (2019c). 2019 European Semester: Assessment of progress on structural reforms, prevention and correction of macroeconomic imbalances, and results of in-depth reviews under Regulation (EU) No 1176/2011, Lithuania. https:/op.europa.eu/en/publication-detail/-/publication/ceab411c-3b6b-11e9-8d04-01aa75ed71a1/language-en

Faisal, M. N. (2010). Analysing the barriers to corporate social responsibility in supply chains: An interpretive structural modelling approach. International Journal of Logistics Research and Applications, 13(3), 179-195. https://doi.org/10.1080/13675560903264968

Forbes. (2011). No, Consumers will Not pay more for green. http://www.forbes.com/sites/csr/2011/07/28/ no-consumers-will-not-pay-more-for-green/\#2715e4857a0blac0ba2b7584

Ganushchak-Efimenko, L., Shcherbak, V., \& Nifatova, O. (2018). Assessing the effects of socially responsible strategic partnerships on building brand equity of integrated business structures in Ukraine. Oeconomia Copernicana, 9(4), 715-730. https://doi.org/10.24136/oc.2018.035

García-Sánchez, I. M., Cuadrado-Ballesteros, B., \& Frias-Aceituno, J. V. (2016). Impact of the institutional macro context on the voluntary disclosure of CSR information. Long Range Planning, 49(1), 15-35. https://doi.org/10.1016/j.lrp.2015.02.004

George, H., \& Antonis, S. (2016). Cultural dimensions and corporate social responsibility: A cross-country analysis. University of the Aegean.

Gligor-Cimpoieru, D. C., \& Munteanu, V. P. (2015). CSR benefits and costs in a strategic approach. Annals of the University of Craiova-Economic Sciences Series, 1(43), 96-105.

Groh, A., Liechtenstein, H., Lieser, K., \& Biesinger, M. (2018). The venture capital and private equity country attractiveness index. https://blog.iese.edu/vcpeindex/ 
Haddock-Fraser, J., \& Fraser, I. (2008). Assessing corporate environmental reporting motivations: Differences between "close to market" and "business -to-business" companies. Corporate Social Responsibility and Environmental Management, 15(3), 140-155. https://doi.org/10.1002/csr.147

Hong, H., Kubik, J. D., \& Scheinkman, J. A. (2012). Financial constraints on corporate goodness (NBER Working Paper No. 18476). https://doi.org/10.3386/w18476

Ioannou, I., \& Serafeim, G. (2012). What drives corporate social performance? The role of nation-level institutions. Journal of International Business Studies, 43(9), 834-864.

https://doi.org/10.1057/jibs.2012.26

Jackson, G., \& Apostolakou, A. (2010). Corporate social responsibility in Western Europe: An institutional mirror or substitute? Journal of Business Ethics, 94(3), 371-394.

https://doi.org/10.1007/s10551-009-0269-8

Jakusonoka, I., \& Zarina, K. (2018). Attractiveness of Latvian, Lithuanian and Estonian venture capital markets for international investors. Science and Studies of Accounting and Finance: Problems and Perspectives, 12(1), 20-27. https://doi.org/10.15544/ssaf.2018.03

Jenkins, H. (2006). Small business champions for corporate social responsibility. Journal of Business Ethics, 67(3), 241-256. https://doi.org/10.1007/s10551-006-9182-6

Jenkins, H., \& Yakovleva, N. (2006). Corporate social responsibility in the mining industry: Exploring trends in social and environmental disclosure. Journal of Cleaner Production, 14(3-14), 271-284. https://doi.org/10.1016/j.jclepro.2004.10.004

Krajnakova, E., Navickas, V., \& Kontautiene, R. (2018). Effect of macroeconomic business environment on the development of corporate social responsibility in Baltic Countries and Slovakia. Oeconomia Copernicana, 9(3), 477-492. https://doi.org/10.24136/oc.2018.024

Kurucz, E. C., Colbert, B. A., \& Wheeler, D. (2008). The business case for corporate social responsibility. In The Oxford Handbook of Corporate Social Responsibility. Oxford University Press. https://doi.org/10.1093/oxfordhb/9780199211593.003.0004

Laudal, T. (2011). Drivers and barriers of CSR and the size and internationalization of firms. Social Responsibility Journal, 7(2), 234-256. https://doi.org/10.1108/17471111111141512

Lu, J., Ren, L., He, Y., Lin, W., \& Streimikis, J. (2019b). Linking corporate social responsibility with reputation and brand of the firm. Amfiteatru Economic, 21(51), 442-460. https://doi.org/10.24818/EA/2019/51/422

Lu, J., Ren, L., Lin, W., He, Y., \& Streimikis, J. (2019a). Policies to promote Corporate Social Responsibility (CSR) and assessment of CSR impacts. Ekonomie a Management, 22(1), 82-98. https://doi.org/10.15240/tul/001/2019-1-006

Lu, J., Ren, L., Qiao, J., He, Y., \& Lin, W. (2019c). Female executives and corporate social responsibility performance: A dual perspective of differences in institutional environment and heterogeneity of foreign experience. Transformations in Business \& Economics, 18(2), 174-196.

Mbogoh, E., \& Ogutu, P. M. (2017). Challenges of implementing corporate social responsibility strategies by commercial banks in Kenya. Journal of Business and Strategic Management, 2(2), 1-16.

Pawlik, T., Gaffron, P., \& Drewes, P. A. (2012). Corporate social responsibility in maritime logistics. In D. Song \& P. Panayides (Eds.), Maritime logistics (pp. 205-226). Emerald Group Publishing Limited. https://doi.org/10.1108/9781780523415-011

Pimentel, L. V., Branca, A. S., \& Catalao-Lopes, M. (2016). International comparisons of corporate social responsibility. https://www.omicsonline.org/open-access/international-social-comparisons-of-corporate-responsibility-2162-6359-1000327.php?aid=70659

Pruzan-Jorgensen, P. M., \& Farrag, A. (2010). Sustainability trends in the container shipping industry: A future trends research summary. https://www.bsr.org/reports/BSR_Sustainability_Trends_Container_Shipping_Industry.pdf 
Servaes, H., \& Tamayo, A. (2013). The impact of corporate social responsibility on firm value: The role of customer awareness. Management Science, 59(5), 1045-1061. https://doi.org/10.1287/mnsc.1120.1630

Shen, L., Govindan, K., \& Shankar, M. (2015). Evaluation of barriers of corporate social responsibility using an analytical hierarchy process under a fuzzy environment - A textile case. Sustainability, 7(3), 3493-3514. https://doi.org/10.3390/su7033493

Sinha, S. N., \& Chaudhari, T. (2018). Impact of CSR on learning outcomes. Management of Environmental Quality: An International Journal, 29(6), 1026-1041. https://doi.org/10.1108/MEQ-02-2018-0039

Sowden, P., \& Sinha, S. (2005). Promoting health and safety as a key goal of the corporate social responsibility agenda. http://www.hse.gov.uk/research/rrpdf/rr339.pdf

Steurer, R. (2010). The role of governments in corporate social responsibility: Characterising public policies on CSR in Europe. Policy Sciences, 43(1), 49-72. https://doi.org/10.1007/s11077-009-9084-4

Steurer, R., Martinuzzi, A., \& Margula, S. (2012). Public policies on CSR in Europe: Themes, instruments, and regional differences. Corporate Social Responsibility and Environment Management, 19(4), 206-227. https://doi.org/10.1002/csr.264

Szwajca, D. (2018). Relationship between corporate image and corporate reputation in Polish banking sector. Oeconomia Copernicana, 9(3), 493-509. https://doi.org/10.24136/oc.2018.025

The Boston Consultant Group. (2011). Charting a new course: restoring profitability to container shipping. http://www.doc88.com/p-9292322762022.html

West, B., Hillenbrand, C., \& Money, K. (2015). Building employee relationships through corporate social responsibility: The moderating role of social cynicism and reward for application. Group \& Organization Management, 40(3), 295-322. https://doi.org/10.1177/1059601114560062

World Economic Forum. (2019). The Global Competitiveness Report 2019. http://www3.weforum.org/ docs/WEF_TheGlobalCompetitivenessReport2019.pdf

Yuen, K. F., \& Lim, J. M. (2016). Barriers to the implementation of strategic corporate social responsibility in shipping. The Asian Journal of Shipping and Logistics, 32(1), 49-57.

https://doi.org/10.1016/j.ajsl.2016.03.006 